\title{
Non-wood forest products for livelihoods
}

\author{
Productos forestales no maderables como medios de vida
}

\author{
Nataliya Stryamets ${ }^{a, b *}$ \\ *Corresponding author: ${ }^{a}$ Swedish University of Agricultural Sciences, School for Forest Management, \\ Faculty of Forest Sciences, Po Box 43, SE 73921 Skinnskatteberg, Sweden, natalie.stryamets@slu.se \\ ${ }^{\mathrm{b}}$ Roztochya Nature Reserve, Sitchovyh Stryltsiv 7, Ivano-Frankove, 81070, Ukraine.
}

\begin{abstract}
SUMMARY
Forests provide a diversity of non-wood forest products as a resource base for regional and rural development. The role of non-wood forest products differs in time and space. The aim of the study was to analyze the role of non-wood forest products in livelihoods, especially forest-dependent communities, in Ukraine and Sweden. 114 interviews with local stakeholders in two countries were done for this study. The results showed that (1) non-wood forest products have potential for economic rural development, (2) traditional practices of non-wood forest products utilization were retained and revived in Ukraine, (3) and were no longer economically but rather socially important for local people in Sweden. Non-wood forest products have great potential for sustainable rural development, as resources for economic development.
\end{abstract}

Key words: sustainable forest management, sustainable rural development, sustainable livelihoods, Ukraine, Sweden

\section{RESUMEN}

Los bosques proveen una diversidad de productos forestales no maderables (PFNM) como recursos base para el desarrollo regional y rural. El rol de los productos forestales no maderables difiere en el tiempo y el espacio. El objetivo del estudio fue analizar el rol de los productos forestales no maderables como medio de vida, especialmente en las comunidades dependientes del bosque, en Ucrania y Suecia. Se llevaron a cabo 114 entrevistas con actores sociales locales. Los resultados muestran que (1) productos forestales no maderables tienen un potencial en el desarrollo económico de las comunidades rurales, (2) los patrones tradicionales de uso de los productos forestales no maderables han sido retenidos y revividos en Ucrania, (3) los productos forestales no maderables ya no son económicamente relevantes en Suecia pero sí tienen una importancia social. Los productos forestales no maderables tienen un gran potencial para un desarrollo rural sustentable, como recursos para el desarrollo económico.

Palabras clave: manejo forestal sustentable, desarrollo rural sustentable, medios de vida sustentables, Ucrania, Suecia.

\section{INTRODUCTION}

Globally, forest resources and products are fundamental for the livelihoods of a large part of the world's population (FAO 1999). Forests provide a diversity of non-wood forest products (NWFPs) as a resource base for regional and rural development. NWFPs are defined as goods of biological origin other than wood, derived from forests, wooded lands and trees outside forests (FAO 1999). Presently, estimates indicate that $80 \%$ of the population in developing countries uses NWFPs to meet some of their nutritional needs and provide herbal medicine (FAO 1999). Additionally, NWFPs have potential to contribute to local livelihoods, providing resources for value-added products such as jams, extracts for medicines, vitamins, and antioxidants. Also in developed countries, where locals were dependent on NWFPs in the past, and actually continue to provide important social and cultural values for local households (Kardell 1980, Janse and Ottitsch 2005, Forest Europe 2011, Stryamets et al. 2012).
In this study, we analyze the role of NWFPs in livelihoods, especially forest-dependent communities. The sustainable livelihoods approach seeks to improve rural development policy and practice by recognizing the seasonal and cyclical complexity of livelihood strategies (Allison and Ellis 2001). The aim of this study was to analyze the role of NWFPs for different groups of forest stakeholders in rural landscapes in Ukraine and Sweden in order to define the contribution of these forest resources to local livelihoods in countries with different economic and socialcultural conditions.

\section{METHODS}

We conducted qualitative semi-structured interviews (Kvale 2007) with local forest stakeholders. In total, 54 interviews were taken in 26 settlements and towns in Ukrainian Roztochya and 60 interviews in 36 settlements and towns in Swedish Småland. The interviews were taken with different groups of stakeholders including villagers in sett- 
lements with different population size located at different distances to the forest and managers of forest enterprises.

Roztochya, the Ukrainian case study, is located in the western part of Ukraine and eastern Poland, and forms the watershed between the Baltic and Black Sea catchments (Stryamets et al. 2012). The Ukrainian part of Roztochya is situated in the temperate lowland forest eco-region, and covers $992 \mathrm{~km}^{2}$. It is an important green infrastructure that forms a corridor for biodiversity and cultural heritage. Forests cover $c a .44 \%$ of the total area and the rest is made up by agricultural land, cultural woodlands and villages. The population density is about 80 persons $\mathrm{km}^{-2}$ (Stryamets et al. 2012).

Småland, the Swedish case study, is located in the central part of the region with the same name, an upland area in southern Sweden, the core of which forms the southernmost larger island of boreal forest in the country. Nonindustrial private forest owners own $80-85 \%$ of the forests in the study area. The study area encompassed 22 parishes with a total area of $1792 \mathrm{~km}^{2}$, and an average population density of 53 persons $\mathrm{km}^{-2}$. The population trend is negative, especially in rural areas which host $26 \%$ of the population (Stryamets et al. 2012).

\section{RESULTS}

Roztochya (Ukraine). All interviewees collected wild berries. Around $60 \%$ of local people collected at least four different species of berries, namely wild strawberries [Fragaria vesca L.] (on average two liters), blueberries [Vaccinium myrtillus L.] (on average 10 liters), blackberries [Rubus caesius L.] (on average 10 liters) and raspberries [Rubus idaeus L.] (on average 6 liters). The maximum number of collected species was eight, i.e., including also lingonberries [Vaccinium vitis-idaea L.], guelder rose [Viburnum opulus L.], common hawthorn [Crataegus monogyna Jacq.] and rowan [Sorbus aucuparia L.]. The berries collected for sale were wild strawberries, blueberries, blackberries and raspberries. Collection of medical herbs was popular. On average, five species of medical herbs in forests were collected by each household. Almost $96 \%$ of the respondents also collected mushrooms for own consumption and for sale such as penny bun or cep [Boletus edulis Bull. ex Fr.], red-capped scaber stalk [Leccinum aurantiacum (Bull. ex Fr.) S. F. Gray)], honey fungus [Armillaria mellea (Vahl. ex Fr.) Kumm.] and birch bolete (Leccinum scabrum Bull. Gray]. The respondents stated that not more then $10 \%$ of local people in the region hunted regularly. Most hunters came from the larger towns and cities near Roztochya. These hunter typically hunted ducks [Anas platyrhynchos L.], hare [Lepus europeus L.], fox [Vulpes vulpes L.], roe deer [Capreolus capreolus L.] and wild boar [Sus scrofa L.]. Some interviewees reported that they earned more than 3,000 $\mathrm{UAH}^{1}$

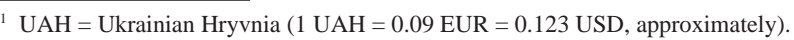

(approximately 300 EUR, equivalent to two monthly salaries in rural areas) per season from selling berries. The price for one litre of blueberries was on average 10-15 UAH, which means that people collected and sold approximately 200 litres of berries. The price for one litre of wild strawberries was around 50 UAH (approximately 5 EUR), one kilogram of penny bun was 60 UAH (approximately 6 EUR). The respondents did not like to talk about the amount of money that they could earn from selling mushrooms and berries, but they pointed out that they could live on that money for several months. Local people sold berries and mushrooms on the markets in the nearest cities and towns, and along the main roads in the region. Interviewees mentioned that one could earn $100 \mathrm{UAH}$ (approximately 10 EUR) per day, which was more than the mean daily labour payment in rural areas. The distance to markets was 2 to $60 \mathrm{~km}$. In villages located close to the border with Poland, local people sold berries (mostly blueberries) to foreign companies, which transported berries to Poland to produce value-added products. Respondents mentioned that it was easy to sell to the Polish companies, because they bought all collected berries. The average price for one litre of blueberries was $10 \mathrm{UAH}$ (approximately 1 EUR). Local people also collected NWFPs for their own needs. All respondents mentioned that it was a tradition to cook dishes including NWFPs for religious holidays, Christmas. Observation of this tradition was important even for respondents for whom collection of mushrooms was not an economic or subsistence activity. People collected berries for their kids because it was a clean and healthy product. The respondents that hunted mentioned that they used meat for food. Some people stated that picking berries and mushrooms was like a hobby. Nearly $90 \%$ of the respondents said that their parents had taught them to pick berries and mushrooms; however, some stated that nowadays kids would rather spend time with computers instead of going to the forest. A majority of the respondents mentioned that the collection of NWFPs had became more intensive compared to 20-25 years ago. One of the reasons was that, during the Soviet period, people had jobs and there was no time and need to collect NWFPs to earn money. However at present, unemployment was high and the forest provided an opportunity to support often scarce livelihoods.

Småland (Sweden). In the Swedish case study, local people harvested NWFPs only for personal use. Almost $80 \%$ of interviewed local people collected berries mainly for making pies for immediate use (blueberry pie). The amount of collected berries varied from 0.5 to 90 litres, and on average it was 2-5 litres of blueberries per family. Several respondents also made preserves for their own consumption during winter. Chanterel cantharellus (L.) Murrill and Craterellus tubaeformis (Fr.) Quel were collected once or twice per season for immediate cooking. Local people did not collect any medical herbs in this region. The tradition 
to hunt and use meat for traditional food like game meat with wild mushrooms was popular in the study area. More than $40 \%$ of respondents stated that at least one member of their family was an active hunter. The most popular species to hunt were moose [Alces alces L.], roe deer, wild boar, hare [Lepus timidus L.] and ducks. The hunters mentioned that they got good ecological meat for free. The meat was used for domestic consumption; only one respondent mentioned selling small amounts of meat. Many respondents stated that collection of berries and mushrooms for food and to sell was important for livelihoods in the region 60-70 years ago. Even 20 years ago, it was more common to pick different berries and mushrooms for food. The respondents pointed out that, nowadays, one could buy everything in the stores. Among the respondents, people of middle age and older were most interested in harvesting NWFPs, especially if the practice was a tradition in their families and they have lived permanently in the countryside. Respondents claimed that as a result, the berry and mushroom yields had become reduced during recent years. Intensive forest management was mentioned by the respondents as a reason for decreasing quantities of berries and mushrooms in forests.

\section{DISCUSSION}

This study shows that local populations in forested regions have used NWFPs for domestic and economic purposes for centuries, and continue to do so. The traditional knowledge about different NWFPs, collection methods, processing, storage, and use, which have been passed through generations, was deeper among local people in Ukraine than in Sweden. By contrast, hunting was more popular, accepted, relied on old traditions and better organized in Sweden, while in Ukraine it was of minor importance to local people. At present, however, the role of NWFPs for local livelihoods is clearly different in Ukraine and Sweden, and this is mainly linked to differences in economic development. In Ukraine selling NWFPs for economic benefit and the recreational and cultural aspect of collecting NWFPs in Sweden were important.

To understand a role of NWFPs in sustainable rural development, economic valuation of forest resources need to be done. First, we need to classify the forest products concerning rivalry and excludability. Forest products are divided by level of rivalry and chance to exclude potential users of forest resources (Sandström et al. 2011). As a result, forest products could be classified as: (i) private goods (could belong only to one individual), (ii) public goods (could be use by general public and are not limited in quantity), (iii) club goods (limited by special fee or restriction), and (iv) common pool goods (could be used by everyone, but are limited in quantity). For resources which are rival and excludable, they are marketable and it is easy to put the price. For public goods, which are open for public and every one could benefit from them; for example, a nice view of coniferous forest in winter, it is impossible or very difficult to estimate its monetary value. Free riders, in this case, are companies which collect berries in Sweden using the immigrants working potential. This problem already causes a discussion about the free access to berries picking with commercial aim (Sandell and Fredman 2010). But as soon as it would be restrictions and fees towards the collection of berries, it would move to the club goods or even to private goods. Hunting is well organized in the Swedish case study (Boman et al. 2011), because it is private goods and it is rival and excludable. Other NWFPs, like berries, mushrooms and medical herbs are rivals, because if one would pick all berries other could not. But they are non-excludable because everyone in both case studies could collect them. The club goods are nonrival, but they are excludable, e.g. entrance fee in national park, horse riding club membership, or BR territory, to become a part of you have to apply.

\section{CONCLUSIONS}

Traditional knowledge and traditional ways of using the NWFPs are present in both countries, but there is a risk to loose such knowledge, because of the depopulation of rural areas, increased welfare, and development of other interests than nature, and people's disconnection from nature. NWFPs have great potential for sustainable rural development, as resources for economic development e.g. tourism development, traditional food and healthy products. Knowledge about the importance and benefits from the NWFPs should be maintained and developed. To promote sustainable use of NWFPs, forest management should include the interests of the local rural population.

\section{ACKNOWLEDGMENTS}

We thank local people for sharing their knowledge in Roztochya and Småland. The Swedish Institute and Marcus and Amalia Wallenberg foundation provided economic support for this study.

\section{REFERENCES}

Allison E, F Ellis. 2001. The livelihoods approach and management of small-scale fisheries. Marine Policy 25: 377-388.

Boman M, L Mattsson, G Ericsson, B Kriström. 2011. Moose hunting values in Sweden now and two decades ago: the hunters revisited. Environmental Resource Economics 50: 515-530.

FAO (Food and Agriculture Organization of the United Nation). 1999. Towards a harmonized definition of non-wood forest products. Unasylva 198: 63-64.

Forest Europe. 2011. State of Europe’s Forests 2011. Status and trends in sustainable forest management in Europe. UNECE and FAO. Available in: http://www.foresteurope.org/ filestore/foresteurope/Publications/pdf/State_of_Europes_ Forests_2011_Report_Revised_November_2011.pdf 
Janse G, A Ottitsch. 2005. Factors influencing the role of NonWood Forest Products and Services. Forest Policy and Economics 7: 309-319.

Kardell L. 1980. Forest berries and mushrooms: an endangered resource? Ambio 9(5): 241-247

Kvale S. 2007. Doing interviews. London, UK. Sage Publications. 157 p.

Sandell K, P Fredman. 2010. The Right of Public Access - Opportunity or Obstacle for Nature Tourism in Sweden? Scandi- navian Journal of Hospitality and Tourism 10(3): 291-309. Sandström C, A Lindkvist, K Öhman, EM Nordström. 2011. Governing competing demands for forest resources in Sweden. Forests 2: 218-242.

Stryamets N, M Elbakidze, P Angelstam. 2012. Role of nonwood forest products for local livelihoods in countries with transition and market economy: case studies in Ukraine and Sweden. Scandinavian journal of forest research 27(1): 74-87.

Recibido: 24.05.12

Aceptado: 10.10 .12 